\title{
Analisis Kinerja, Disiplin, dan Produktivitas Kerja Karyawan Dalam Mempengaruhi Pemanfaatan Sistem Informasi Sumber Daya Manusia
}

\author{
Gugus Wijonarko \\ Program Studi Ilmu Administrasi Bisnis, STIAMAK Barunawati Surabaya, Jawa Timur \\ Email: gugus.wijonarko@stiamak.ac.id
}

(Naskah masuk: 9 Okt 2021, direvisi: 22 Okt 2021, 30 Okt 2021, diterima: 3 Nov 2021)

\begin{abstract}
Abstrak
Era digital secara konsep menuntut pemanfaatan teknologi pada seluruh aspek pekerjaan manusia, khususnya adanya sinergi dan hubungan antara teknologi dengan faktor manusia yang dianggap sebagai salah satu aset perusahaan. Tujuan penelitian ini adalah untuk mengukur dan mengetahui faktor-faktor yang membuat karyawan memutuskan untuk menggunakan aplikasi sistem informasi sumber daya manusia dalam rutinitas pekerjaan dengan melihat pada variabel penelitian manajemen SDM yaitu kinerja, disiplin, dan produktivitas kerja dalam mempengaruhi keputusan menggunakan aplikasi HRIS. Sampel penelitian ini adalah pengguna dari beberapa perusahaan di Surabaya yang menggunakan aplikasi HRIS dalam rutinitas operasional pekerjaan sehari-hari mereka. Pada penelitian ini ditemukan sampel penelitian sebanyak 55 responden dari berbagai perusahaan di Surabaya dan hasil tanggapan responden tersebut dilakukan pengolahan data menggunakan teknik analisis data regresi linear berganda dengan tingkat kepercayaan 95\% dan pembuktian hipotesis menggunakan uji $\mathrm{T}$ dan uji $\mathrm{F}$. Hasilnya adalah faktor kinerja karyawan dan faktor disiplin mempengaruhi secara signifikan keputusan pengguna menggunakan sistem informasi sumber daya manusia. Hal ini dikarenakan para responden merasa adanya urgensi terhadap proses pencatatan adminsitrasi yang lebih baik. Sedangkan untuk variabel produktivitas kerja tidak mempengaruhi keputusan penggunaan aplikasi SISDM dikarenakan aplikasi hanya dipandang sebagai alat penunjang operasional pekerjaan sehari hari.
\end{abstract}

Kata Kunci: Sumber Daya Manusia, Kinerja Karyawan, Disiplin, Produktivitas Kerja, Sistem Informasi.

\section{Analysis of Employee Performance, Discipline, and Work Productivity In Influencing Utilization of Human Resource Information Systems}

\begin{abstract}
The digital era conceptually demands the use of technology in all aspects of human work, especially the synergy and relationship between technology and human factors which are considered as one of the company's assets. The purpose of this study is to measure and determine the factors that make employees decide to use human resource information system applications in their work routines by looking at the HR management research variables, namely performance, discipline, and work productivity in influencing decisions to use the HRIS application. The sample of this research is users from several companies in Surabaya who use the HRIS application in their daily work operational routines. In this study, it was found that the research sample was 55 respondents from various companies in Surabaya and the results of the respondents' responses were processed using multiple linear regression data analysis techniques with a 95\% confidence level and hypothesis verification using $T$ test and $F$ test. The result is that employee performance factors and discipline factors significantly influence user decisions to use human resource information systems. This is because the respondents feel there is an urgency for a better administrative recording process. While for work productivity variables it does not affect the decision to use the SISDM application because the application is only seen as a tool to support day-to-day work operations.
\end{abstract}

Keywords: Human Resources, Employee Performance, Discipline, Work Productivity, Information Systems. 


\section{PENDAHULUAN}

Secara umum Sumber Daya Manusia (SDM) adalah penggerak dalam organisasi. Oleh karena itu tidak salah bila dewasa ini, SDM dapat dipandang sebagai aset yang bernilai dan berharga. Karyawan sebagai salah satu bentuk sumber daya manusia tidak lagi dipandang sebagai alat, tapi merupakan bagian dari perusahaan yang memiliki peranan sebagai motor pengerak untuk mencapai tujuan perusahaan [1].

Pentingnya peran SDM ini dikarenakan dalam pekerjaannya seorang karyawan berinteraksi langsung dengan sumber daya perusahaan lainnya, seperti modal, material, metode, dan mesin [2]. Maka dari itu untuk menunjang peran SDM tersebut dalam institusi bisnis, kerja dari SDM ini perlu ditopang oleh penggunaan teknologi, khususnya pemanfaatan aplikasi Sistem Informasi Sumber Daya Manusia (SISDM).

Penggunaan metode konvensional masih sering dilakukan. Sebagai contoh adalah adanya perusahaan yang masih melakukan pencatatan secara manual. Pencatatan semacam ini sudah mulai dianggap tidak relevan atau sudah tidak cocok dengan kondisi bisnis saat ini dikarenakan rentan menyebabkan terjadinya banyak kesalahan seperti adanya kemungkinan resiko, terjadinya pengambilan keputusan yang sifatnya subyektif, kurang dinamis, dan kurang fleksibel kinerja yang dilakukan oleh karyawan, serta waktu yang digunakan untuk menyelesaikan suatu pekerjaan akan menjadi telalu lama [3].

Pemanfaatan aplikasi sistem informasi SDM berpotensi menghasilkan benefit atau keuntungan bagi perusahaan. Sebagai contoh, secara teoritis terdapat dua sasaran utama dalam pelaksanaan operasional organisasi, antara lain adalah adanya kemungkinan untuk pengurangan biaya yang berdampak pada peningkatan efisiensi, meminimalkan penggunaan sumber daya material seperti kertas, dan meningkatkan secara maksimal proses pengiriman data dan informasi. Termasuk juga dalam bagian dari rencana peningkatan efektivitas dari kinerja organisasi tersebut [4]. Bagian dari sistem informasi sumber daya manusia menurut Sinamora tahun 2009 dikutip oleh Rosadi \& Purnomo tahun 2020 [5] adalah:

1. Tepat Waktu: aplikasi sistem informasi yang menangani sumber daya manusia harus mampu memutakhirkan informasi sehingga dapat membantu pengambilan keputusan dengan lebih baik.

2. Akurat: informasi yang disajikan dalam aplikasi harus akurat dan minim kesalahan atau memiliki ketapatan yang tinggi

3. Informatif dan Ringkas: informasi yang dibutuhkan tidak bertele-tele, sederhana namun mudah untuk dimengerti.

4. Relevan: penyajian informasi yang dikeluarkan oleh sistem sesuai dengan kondisi dan situasi, dimana hanya informasi yang sesuai dengan permintaan pengguna yang menjadi output sistem

5. Lengkap: pengguna sistem harus bisa mendapatkan informasi yang lengkap sesuai dengan penyajian informasi sesuai aspek daya guna.
Beberapa perusahaan telah melakukan pelatihanpelatihan dalam rangka meningkatkan kinerja karyawan mereka dan memberikan pengetahuan kepada mereka untuk memahami modul-modul dalam penggunaan sistem informasi sumber daya manusia. Kinerja karyawan secara definisi adalah hasil dimana individu atau sekolompok pekerja bersama-sama membawa hasil akhir yang didasarkan pada tingkat mutu dan standar yang telah ditetapkan [1]. Komponen-komponen yang merupakan bagian dari penilaian kinerja karyawan antara lain adalah: (1) kualitas kerja karyawan, (2) kuantitas kerja, dan (3) kontribusi karyawan terhadap organisasi [2]. Hubungan antara SISDM dengan kinerja sendiri adalah ada kebijakan atau prosedur dan praktik maupun sistem yang dapat mempengaruhi perilaku, sikap, dan kinerja karyawan itu sendiri [6].

Tingkat kedisiplinan menjadi salah satu hal yang utama dalam lingkup organisasi. Secara definisi, disiplin adalah tindakan manajemen dalam melaksanakan standar organisasi dalam melibatkan sikap dan perilaku karyawan [2]. Disiplin pada dasarnya dapat dipandang sebagai alat untuk memodifikasi perilaku karyawan yang memiliki peluang terjadinya masalah dalam organisasi. Hal ini juga sebagai bagian dari evaluasi karyawan yang memiliki kecenderungan tidak produktif agar memiliki kehendak untuk mengikuti atau mematuhi aturan dan keputusan perusahaan yang telah ditetapkan sebelumnya [7]. Indikator atau bagian dari disiplin menurut Mathis \& Jackson tahun 2002 dikutip oleh Lasmaya tahun 2016 [7] meliputi: (1) disiplin positif dan (2) disiplin progresif.

Produktivitas adalah hasil atau bentuk dari pekerjaan secara nyata yang dihasilkan oleh karyawan dalam bekerja, baik secara perorangan maupun di dalam kelompok dalam satuan waktu. Produktivitas juga merupakan bentuk dari perbandingan antara luaran/output yang dihasilkan berbanding dengan penggunaan sumber daya perusahaan sebagai masukan dalam proses bisnisnya [8]. Produktivitas dipengaruhi oleh dua hal, yaitu [9]:

1. Faktor Internal: berupa komitmen kepada organisasi, struktur dan desain pekerjaan, motivasi, etos kerja dan disiplin, dukungan sumber daya yang dimiliki oleh perusahaan, peraturan dan kebijakan perusahaan. Selain itu juga dapat berupa adanya suasana kerja yang menyenangkan, praktik manajemen secara konsisten, lingkungan kerja yang aman dan nyaman, ketersesuaian tugas dan komunikasi dalam bekerja antara karyawan.

2. Faktor Eksternal: berupa peraturan dan kebijakan pemerintah, kemitraan, kultur dan lingkungan sekitar organisasi, tingkat persaingan, dan dampak globalisasi

Secara tidak langsung, hubungan atau konektivitas antara sistem informasi sumber daya manusia dengan konsep produktivitas kerja adalah penggunaan SISDM dapat membentuk pola kreativitas dalam organisasi dengan berorientasi pada daya produktivitas dan efisiensi proses kerja, seperti penghematan biaya dalam menggunakan sumber daya organisasi [10].

Berdasarkan pada pendahuluan di atas maka penelitian ini bertujuan untuk mengetahui hubungan antara analisis faktor kinerja, disiplin, dan produktivitas kerja yang mempengaruhi 
keinginan dan pengambilan keputusan para pekerja dalam praktik manajemen dengan menggunakan Sistem Informasi Sumber Daya Manusia pada lingkup kerja masing masing agar pekerjaan dapat menjadi lebih efektif dan efisien.

\section{METODOLOGI PENELITIAN}

\section{A. Desain Penelitian}

Proses rancangan atau skema penelitian yang dilakukan adalah sebagai berikut:

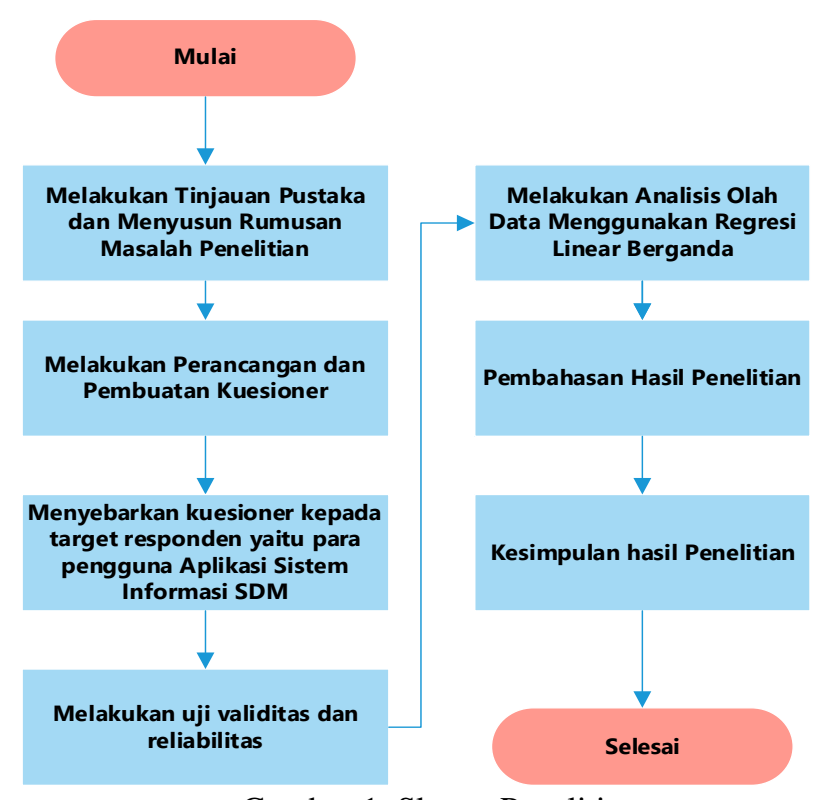

Gambar 1. Skema Penelitian

Pada Gambar 1 dijabarkan bahwa skema penelitian yang dilakukan adalah dengan melakukan tinjauan literatur kepada penelitian terdahulu dan melakukan perumusan masalah yang akan diangkat dalam penelitian ini. Pada tahapan selanjutnya dilakukan perancangan dan pembuatan kuesioner dan menyebarkan kepada target responden yang telah ditentukan sebelumnya, Hasil yang didapatkan dari penyebaran kuesioner ini selanjutnya dilakukan pengecekan kelayakan melalui uji validitas dan reliabilitas untuk mengukur kehandalan dan konsistensi dari jawaban responden yang telah dikumpulkan. Pada tahapan selanjutnya dilakukan proses pengolahan data menggunakan analisis regresi linear berganda. Hasil yang diperoleh dari olah data kemudian dilakukan pembahasan dan penarikan kesimpulan dari penelitian yang telah dilakukan.

Sedangkan hubungan antara setiap variabel penelitian berdasarkan pada faktor kinerja karyawan, disiplin kerja, dan produktivitas kerja karyawan dalam memutuskan menggunakan sistem informasi sumber daya manusia maka dirumuskan hubungan antara variabel seperti pada Gambar 2 berikut ini:

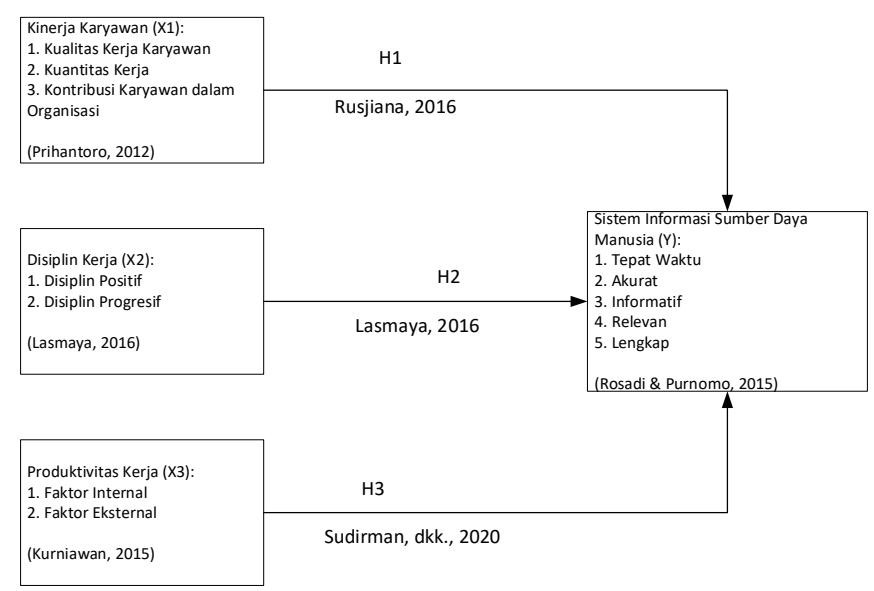

Gambar 2. Hubungan Antar Variabel

Dari gambaran pada model peneltian seperti pada Gambar 2 di atas dan berdasarkan tinjauan penelitian terdahulu dari hubungan antar variabel penelitian maka dapat dirumuskan hipotesis dalam penelitian ini adalah sebagai berikut:

H1. Kinerja karyawan berpengaruh terhadap penggunaan SISDM

H2. Disiplin karyawan berpengaruh terhadap pemanfaatan aplikasi SISDM

H3. Produktivitas karyawan berpengaruh terhadap pemanfaatan aplikasi SISDM

\section{B. Tinjauan Penelitian Terdahulu}

Penelitian terdahulu mengambil beberapa literatur dari jurnal ilmiah yang sesuai dengan topik yang dibahas yaitu:

1. Penelitian dengan judul pengaruh Sistem Informasi Sumber Daya Manusia (SISDM) terhadap kinerja karyawan di PT. Rabbani Bandung dengan menggunakan sampel responden sebesar 36 dan metode pengolahan data SEM-PLS. Dari penelitian tersebut didapatkan hasil bahwa penggunaan aplikasi SISDM memiliki dampak untuk meningkatkan kinerja karyawan, dengan memperhatikan prosedur dan tahapan yang telah ditentukan perusahaan [6].

2. Penelitian dengan judul pengaruh SISDM, kompetensi, dan disiplin kerja terhadap kinerja karyawan dengan total responden sebesar 36 dan menggunakan metode analisis jalur. Hasil yang didapatkan adalah pengaruh dari ketiga variabel dinyatakan signifikan [7].

3. Penelitian ketiga berjudul The Implementation of Human Resources Information System and It's Benefit for Organizations. Dengan sampel penelitian sebanyak 80 responden dan menggunakan metode uji asumsi klasik dan diperoleh hasil bahwa penggunaan SISDM terbukti memiliki dampak dalam optimalisasi efisiensi biaya [11].

\section{Teknik Analisis Data}

Dalam melakukan analisis data dilakukan beberapa tahapan uji seperti uji validitas untuk mengukur dan menentukan tingkatan dari data apakah data tersebut layak dan terpercaya untuk digunakan. Sedangkan uji reliabilitas untuk mengetahui kehandalan dari alat ukur penelitian 
seperti penggunaan kueisoner atau dalam bentuk item lainnya [12].

Dalam penelitian ini akan menggunakan metode kuantitatif. Metode kuantitatif secara definisi merupakan metode penelitian yang menjelaskan sebuah masalah dan hasilnya dapat dipahami secara umum. Atau dengan kata lain diartikan pula bahwa metode kuantitatif merupakan metode yang melakukan hubungan kausal antara variabel penelitian menggunakan model pengaruh hubungan sebab akibat [13]. Metode pengumpulan data yang dilakukan adalah dengan menyebarkan kuesioner kepada karyawan atau responden yang pada perusahaannya dalam operasional sehari-hari telah menggunakan aplikasi sistem informasi sumber daya manusia.

\section{Pengertian Populasi dan Sampel}

Populasi dalam penelitian ini adalah karyawan atau pengguna yang dalam operasional pekerjaan sehari-harinya diperusahaan mereka masing-masing telah menggunakan aplikasi SISDM dan sampel responden yang didapatkan dari penyebaran kuesioner ini didapatkan sebesar lima puluh lima orang. Hal ini merujuk kepada pernyataan dari Roscoe yang dikutip oleh Girija Tahun 2019 yang menyatakan bahwa ukuran sampel harus lebih dari tiga puluh atau bila melakukan analisis multivariat seperti korelasi atau regresi linear berganda maka jumlah sampel adalah jumlah variabel penelitian baik variabel bebas dan terikat, dikali dengan sepuluh [14]. Dalam penelitian ini memiliki empat variabel maka minimum sampel yang diperkenankan adalah empat dikali sepuluh sehingga mendapatkan hasil empat puluh.

\section{HASIL DAN PEMBAHASAN}

\section{A. Uji Validitas dan Uji Reliabilitas}

Uji validitas adalah bentuk langkah pengujian yang dilakukan terhadap butir atau item pernyataan kuesioner yang digunakan dalam penelitian ini yang bertujuan untuk mengukur tingkat akurasi atau mengukur tingkat kepercayaan dari data pernyataan yang terdapat dalam kuesioner/angket yang telah disebarkan kepada sampel responden tersebut [12].

Butir-butir dari kuesioner yang digunakan ini diambil dari penelitian terdahulu dan pada uji validitas akan menguji kelayakan pernyataan yang akan digunakan dalam kuesioner. Sebuah kuesioner akan dianggap layak untuk digunakan bila memiliki korelasi secara signifikan terhadap nilai dari skor total pernyataan kuesioner yang digunakan. Proses pengujian ini dilakukan dengan membandingkan nilai dari hasil $r$ hitung terhadap nilai dari tabel $r$. Jenis metode uji validitas yang digunakan dalam penelitian ini adalah metode korelasi total item yang dikoreksi [15]. Hasil pengujian validitas dari kuesioner dengan menggunakan aplikasi SPSS didapatkan hasil seperti pada Tabel 1 berikut ini:
Tabel 1. Hasil Uji Validitas

\begin{tabular}{llll}
\hline $\begin{array}{c}\text { Variabel } \\
\text { Pernyataan }\end{array}$ & r tabel & $\mathbf{r}$ hitung & Keterangan \\
\hline $\mathrm{x} 1$ & 0,270 & 0,793 & Valid \\
\hline $\mathrm{x} 2$ & 0,270 & 0,780 & Valid \\
\hline $\mathrm{x} 3$ & 0,270 & 0,779 & Valid \\
\hline $\mathrm{x} 4$ & 0,270 & 0,890 & Valid \\
\hline $\mathrm{x} 5$ & 0,270 & 0,826 & Valid \\
\hline $\mathrm{y} 11$ & 0,270 & 0,799 & Valid \\
\hline $\mathrm{y} 12$ & 0,270 & 0,570 & Valid \\
\hline $\mathrm{y} 13$ & 0,270 & 0,940 & Valid \\
\hline $\mathrm{y} 21$ & 0,270 & 0,574 & Valid \\
\hline $\mathrm{y} 22$ & 0,270 & 0,782 & Valid \\
\hline $\mathrm{y} 31$ & 0,270 & 0,715 & Valid \\
\hline $\mathrm{y} 32$ & 0,270 & 0,795 & Valid \\
\hline
\end{tabular}

Hasil dari uji validitas pada Tabel 1 dengan tingkat kepercayaan sembilan puluh lima persen (95\%). Atau yang berarti didapatkan hasil bahwa dari sebanyak lima puluh lima responden yang mengisi kuesioner, didapatkan derajat kebebasan $(\mathrm{df})=\mathrm{n}-2$ atau $\mathrm{df}=55-2=53$. Jika dibandingkan dengan tabel $r$ dengan tingkat kepercayaan sebesar $95 \%$ atau taraf signifikansi 0,05 , sehingga didapatkan hasil sebesar 0,270. Bila dibandingkan dengan kolom skor total korelasi item pada Tabel 1, maka didapatkan hasil bahwa seluruh nilai dari butir kuesioner berada di atas nilai 0,270. Dapat disimpulkan bahwa kuesioner yang digunakan dalam penelitian ini dapat dinyatakan valid.

Tahapan selanjutnya setelah uji validitas dalam penelitian ini adalah melakukan uji reliabilitas yaitu menggunakan analisis cronbach alpha untuk mengukur apakah kuesioner tersebut dianggap stabil dan reliabel sehingga didapatkan hasil dari uji reliabilitas ditampilkan seperti pada Tabel 2 berikut ini:

Tabel 2. Hasil Uji Reliabilitas

\begin{tabular}{rr}
\hline $\begin{array}{c}\text { Cronbach's } \\
\text { Alpha }\end{array}$ & N Of Items \\
\hline 0,949 & 12 \\
\hline
\end{tabular}

Hasil dari uji reliabilitas menggunakan aplikasi SPSS terhadap dua belas butir pernyataan kuesioner seperti pada Tabel 2 didapatkan hasil sebesar 0,949. Berdasarkan hasil tersebut maka dapat dinyatakan bahwa kuesioner yang digunakan dalam penelitian ini dapat dinyatakan stabil dan reliabel atau memiliki kehandalan dan konsistensi dalam pengunaannya karena memiliki nilai di atas standar yang umumnya ditetapkan yaitu 0,70 [15].

\section{B. Analisis Regresi Linear Berganda}

Analisis data menggunakan regresi linear berganda dilakukan untuk mengetahui dan menjawab rumusan masalah yang telah ditetapkan sebelumnya yaitu apakah sistem informasi sumber daya manusia memiliki pengaruh terhadap kinerja, disiplin, dan produktivitas karyawan. Dari 
hasil pengujian asumsi klasik atau uji multikolinieritas didapatkan hasil seperti pada Tabel 3:

Tabel 3. Hasil Uji Multikolinieritas

\begin{tabular}{lcc}
\hline \multirow{2}{*}{ Model } & \multicolumn{2}{c}{ Collinearity Statistics } \\
\cline { 2 - 3 } & Tolerance & VIF \\
\hline (Constant) & & \\
\hline Kinerja (X1) & 0,450 & 2,221 \\
\hline Disiplin (X2) & 0,251 & 3,984 \\
\hline Produktivitas (X3) & 0,198 & 5,039 \\
\hline
\end{tabular}

Dari hasil pengujian pada Tabel 3 didapatkan hasil perhitungan bahwa nilai tolerance dari masing-masing variabel seperti kinerja, disiplin, dan produktivitas berada diatas standar yaitu 0,10 . Selain itu didapatkan pula hasil bahwa nilai VIF dibawah 10,00 [12]. Maka dari itu hasil ini dapat disimpulkan bahwa keseluruhan data bebas dari uji multikolinearitas, sehingga kesimpulan yang diperoleh adalah data-data pada penelitian ini dapat digunakan dan penelitian dapat dilanjutkan.

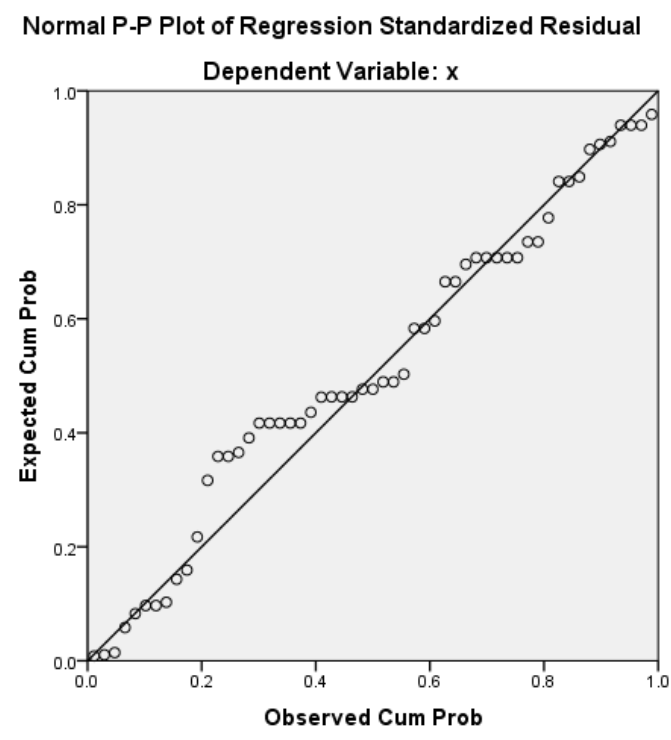

Gambar 3. Uji Normalitas

Hasil dari uji normalitas didapatkan hasil seperti pada Gambar 3 dimana ditunjukkan bahwa titik-titik pada diagram plot mengikuti dari garis diagonal. Dengan demikian dapat dinyatakan bahwa data memiliki distribusi normal dan stabil sehingga data-data yang digunakan pada penelitian ini dapat dilanjutkan [12].

Tabel 4. Analisis Regresi Linear Berganda

\begin{tabular}{lrr}
\hline \multirow{1}{*}{\multicolumn{1}{c}{ Model }} & \multicolumn{2}{c}{$\begin{array}{c}\text { Unstandardized } \\
\text { Coefficients }\end{array}$} \\
\cline { 2 - 3 } & \multicolumn{1}{c}{ B } & Std. Error \\
\hline Constant $)$ & $-0,321$ & 1,216 \\
\hline Kinerja (X1) & 0,957 & 0,113 \\
\hline Disiplin (X2) & 1,041 & 0,329 \\
\hline Produktivitas (X3) & $-0,340$ & 0,323 \\
\hline
\end{tabular}

Penggunaan analisis regresi berganda untuk menjawab dan menguji hipotesis yang telah ditentukan pada penelitian ini. Rumus dari persamaan regresi adalah [12]:

$\mathrm{Y}=\mathrm{a}+\mathrm{b} 1 \mathrm{X}_{1}+\mathrm{b} 2 \mathrm{X}_{2}+\mathrm{b} 3 \mathrm{X}_{3}+\mathrm{e}$

Keterangan dari persamaan regresi adalah:

$\mathrm{Y}=$ Keputusan Penggunaan SISDM

a $=$ Konstanta

b1 = Koefisien regresi $\mathrm{x} 1$ terhadap $\mathrm{Y}$

$\mathrm{b} 2=$ Koefisien regresi $\mathrm{x} 2$ terhadap $\mathrm{Y}$

b3 = Koefisien regresi $\mathrm{x} 3$ terhadap $\mathrm{Y}$

$\mathrm{X}_{1}=$ Variabel Independen Kinerja

$\mathrm{X}_{2}=$ Variabel Independen Disiplin

$\mathrm{X}_{3}=$ Variabel Independen Produktivitas

$\mathrm{e} \quad=$ Error

Dari hasil pada tabel 4 diatas maka dapat dibentuk persamaan sebagai berikut:

$\mathrm{Y}=-0,321+0,957(\mathrm{X} 1)+1,041(\mathrm{X} 2)-0,340(\mathrm{X} 3)+\mathrm{e}$

Maka hasil dari perasamaan regresi tersebut dapat diintepretasikan sebagai berikut:

- Nilai constant yang dihasilkan sebesar -0,321. maka dapat diartikan bahwa tanpa adanya pengaruh dari variabel Kinerja (X1), Disiplin (X2), dan produktivitas (X3) terhadap variabel SISDM (Y), maka variabel Dependen SISDM (X) memiliki nilai sebesar -0,321.

- Koefisien b1 yang dihasilkan bernilai positif yaitu sebesar 0,957. yang berarti bahwa jika variabel Kinerja (X1) mengalami peningkatan sebesar 1 poin atau $1 \%$ dan variabel-variabel lain konstan, maka variabel SISDM (Y) juga mengalami peningkatan sebesar 0,957.

- Koefisien b2 yang dihasilkan bernilai positif sebesar 1,041. Dapat diartikan bahwa jika variabel Disiplin (X2) mengalami peningkatan sebesar 1 poin atau $1 \%$ dan variabel lain konstan maka variabel SISDM (Y) akan mengalami peningkatan sebesar 1,041.

- Koefisien b3 yang dihasilkan bernilai negatif sebesar 0,340, maka hal ini dapat berarti bahwa jika variabel produktivitas (X3) mengalami peningkatan akan menurunkan SISDM (Y) sebesar -0,340.

Tabel 5. Uji Hipotesis F dan t

\begin{tabular}{lcccc}
\hline \multicolumn{1}{c}{ Model } & \multicolumn{2}{c}{ Uji t } & \multicolumn{2}{c}{ Uji F } \\
\hline \multicolumn{1}{c}{ Constant } & t & Sig & F & Sig \\
\hline Kinerja (X1) & 8,471 & 0,000 & & \\
Disiplin (X2) & 3,168 & 0,003 & 79,90 & $0,000^{\mathrm{b}}$ \\
Produktivitas (X3) & $-1,052$ & 0,298 & & \\
\hline
\end{tabular}

Berdasarkan Tabel 5, hasil pengujian secara parsial yang telah dilakukan dapat diketahui bahwa:

\section{- Hipotesis 1: Kinerja karyawan berpengaruh terhadap penggunaan Aplikasi SISDM}

Kinerja (X1) memiliki koefisien B sebesar 0,957 dengan nilai signifikansi sebesar $0,000<0,05$ taraf signifikansi dan memiliki nilai $\mathrm{t}$ hitung sebesar 8,471>2,007 nilai t tabel. 
Dengan demikian dapat disimpulkan bahwa pengaruh Kinerja terhadap pemanfaatan SISDM menghasilkan nilai signifikan positif.

Berdasarkan hasil ini menunjukkan bahwa kinerja karyawan dipengaruhi oleh kualitas pekerjaan, kontribusi, dan kuantitas akan tercapai bila didukung oleh pemanfaatan aplikasi agar pekerjaan menjadi lebih efektif dan efisien. Terbukti dari persepsi para responden yang merupakan karyawan yang pernah menggunakan aplikasi sistem informasi sumber daya manusia menyatakan bahwa kualitas pekerjaan yang baik akan tercapai bila didukung juga oleh pemanfaatan teknologi dalam pekerjaan mereka.

\section{- Hipotesis 2: Disiplin karyawan berpengaruh terhadap pemanfaatan aplikasi SISDM}

Disiplin (X2) memiliki Koefisien B sebesar 1,041 dengan nilai signifikansi sebesar $0,003<0,05$, taraf signifikansi dan memiliki nilai t hitung sebesar 3,168> nilai tabel t yaitu 2,007. Maka kesimpulan yang didapatkan adalah bahwa pengaruh Disiplin terhadap pemanfaatan SISDM hasilnya bernilai signifikan positif.

Hal ini berarti seluruh responden menyatakan setuju bahwa untuk dapat melakukan penerapan disiplin yang baik pada organisasi dan menunjang proses pengambilan keputusan yang obyektif maka penerapan kedisiplinan organisasi harus didukung juga oleh faktor teknologi. Kegiatan manajerial seperti pencatatan kehadiran dan manajemen cuti karyawan, penyelesaian pekerjaan yang tepat waktu, perhitungan tunjangan dan insentif, pemberian penghargaan dan sanksi, perhitungan jam masuk dan jam keluar dan sebagainya akan lebih efektif dan efisien bila dilakukan menggunakan SISDM.

- Hipotesis 3: Produktivitas karyawan tidak berpengaruh terhadap pemanfaatan aplikasi SISDM

Produktivitas (X3) memiliki Koefisien B sebesar -0,340 dengan nilai signifikansi sebesar 0,298 > taraf signifikansi yaitu sebesar 0,05 dan memiliki nilai t hitung sebesar $-1,052$ $<2,007$ nilai t tabel. Dapat disimpulkan bahwa tidak adanya pengaruh produktivitas terhadap pemanfaatan SISDM.

Hasil perhitungan menunjukkan tidak adanya pengaruh hal ini berarti para karyawan merasa bahwa produktivitas dapat tercapai dengan adanya motivasi dari dalam diri karyawan itu sendiri. Pemanfaatan aplikasi dalam konteks produktivitas hanya dipandang sebagai alat bantu pencapai keberhasilan.

Kinerja (X1) dan Disiplin (X2) secara bersama-sama atau simultan memiliki pengaruh yang signifikan terhadap variabel dependen SISDM (Y). Akan tetapi variabel Produktivitas (X3) tidak memiliki pengaruh. Pengaruh dari variabel-variabel ini dapat dibuktikan dengan membandingkan nilai $\mathrm{F}$ hitung dengan nilai $\mathrm{F}$ tabel. Nilai $\mathrm{F}$ hitung yang dihasilkan adalah sebesar 79,90 > 2,773 nilai $\mathrm{F}$ tabel. Serta memiliki nilai signifikansi (sig) sebesar 0,000, dimana nilai signifikansinya berada dibawah angka 0,05 .

Hasil yang diperoleh implementasi SISDM dalam proses manajemen operasional organisasi secara keseluruhan terbukti efektif dan efisien dalam meningkatkan kinerja karyawan dan faktor untuk menerapkan prosedur standar dan penerapan disiplin juga perlu didukung oleh implementasi sistem informasi SDM. Sedangkan untuk produktivitas, kembali kepada kesadaran dan kepedulian dari masingmasing karyawan untuk berusaha mencapai tujuan organisasinya.

\section{KESIMPULAN}

Dari hasil penelitian yang telah dilakukan untuk mengetahui pengaruh dari variabel kinerja karyawan, variabel disiplin karyawan, dan produkvitias kerja karyawan dalam mempengaruhi keputusan menggunakan aplikasi sistem informasi sumber daya manusia, maka didapat kesimpulan bahwa, hipotesis pertama menyatakan bahwa variabel kinerja karyawan berpengaruh signifikan terhadap faktor penggunaan aplikasi SISDM. Hal ini dinyatakan bahwa kinerja karyawan dapat menjadi lebih efektif dan efisien bila didukung oleh penggunaan teknologi khususnya aplikasi yang dapat membantu percepatan pencatan administrasi

Hipotesis kedua menyatakan bahwa variabel disiplin mempengaruhi secara signifikan penggunaan aplikasi sistem informasi sumber daya manusia, Hal ini dikarenakan disiplin dapat tercapai bila ada rasa keadilan diantara karyawan itu sendiri dengan dua indikator yaitu disiplin positif dan disiplin progresif. Kedua indikator ini dapat tercapai dengan baik bila turut pula didukung dengan adanya dokumentasi melalui pemanfaatan aplikasi yang dapat menampilkan informasi yang tepat waktu, relevan, akurat, informatif dan lengkap.

Hipotesis ketiga menyatakan bahwa produktivitas tidak mempengaruhi penggunaan aplikasi sistem informasi sumber daya manusia dalam pekerjaan operasional harian. Hal ini dikarenakan produkvitias dapat tercapai melalui dua faktor yaitu faktor internal dan eksternal. Sedangkan aplikasi hanya merupakan pendukung dalam proses bisnis manajemen operasional harian organisasi.

\section{REFERENSI}

[1] Ratnasari, S.L., B. S. L \& Tanjung, R. (2021). Pengaruh Peranan Sumber Daya Manusia, Pelatihan, Dan Disiplin Kerja Terhadap Kinerja Karyawan. Jenius: Jurnal Ilmiah Manajemen Sumber Daya Manusia, Vol. 4(2), pp. 153-163.

[2] Prihantoro, A. (2012). Peningkatan Kinerja Sumber Daya Manusia Melalui Motivasi, Disiplin, Lingkungan Kerja, dan Komitmen. Value Added: Majalah Ekonomi dan Bisnis, Vol. 8(2), pp. 78-98.

[3] Saefudin \& Wahyuningsih, S. (2014). Sistem Pendukung Keputusan Untuk Penilaian Kinerja Pegawai Menggunakan Metode Analytical Hierarchy Process (AHP) Pada RSUD Serang. Jurnal Sistem Informasi, Vol. 1(1), pp. 33-37.

[4] Subhashree, V. \& Vasantha. (2020). Influence of IT Infrastructure and IT Expertise on E-HRM Adoption. International Journal of Scientific \& Technology 
Research, Vol. 9(1), pp. 585-589.

[5] Rosadi, A.A.S. \& Purnomo, Y.J. (2020). Pengaruh Sistem Informasi Sumber Daya Manusia Terhadap Kinerja Pada Pegawai PT Raudah Utama Cianjur. Jurnal Sains Sosio Humaniora, Vol. 4(2), pp. 357-367. DOI: $10.22437 /$ jssh.v4i2.10865.

[6] Rusjiana, J. (2016). Pengaruh Sistem Informasi SDM Terhadap Kinerja Stuctural Equaltion Modeling SEMPLS. Jurnal Computech \& Bisnis, Vol. 10(1), pp. 2129.

[7] Lasmaya, S. M. (2016). Pengaruh sistem informasi SDM, kompetensi dan disiplin kerja terhadap kinerja karyawan. Jurnal Ekonomi, Bisnis \& Entrepreneurship, Vol. 10(1), pp. 25-43.

[8] Nadiah \& Musa, N. (2016). Pengaruh Gaya Kepemimpinan Transformasional Terhadap Produktivitas Kerja Karyawan Pada PT. Sinar Galesong Mandiri Kota Makasar. Balance: Jurnal Ekonomi, Vol. 12(2), pp. 83-96.

[9] Kurniawan, D. (2015). Pengaruh Gaya Kepemimpinan Tranformasional dan Kompensasi Terhadap Produktivitas Kerja Karyawan PT. Sport Glove Indonesia [Skripsi]. Universitas Negeri Yogyakarta.

[10] Sudirman, A et al. (2020). Sistem Informasi Manajemen, 1st ed. Medan: Yayasan Kita Menulis.

[11] Suharti, L.S. \& Sulistyo, P.R. (2018). The
Implementation of Human Resources Information System and It's Benefit for Organizations," Diponegoro International Journal of Business, Vol. 1(1), pp. 1-7, DOI: 10.14710/dijb.1.1.2018.1-7.

[12] Tanjaya, S.C., Manake, L.L. \& Tawas, H.N. (2019). Pengaruh Kualitas Informasi, Kepercayaan Dan Kemudahan Konsumen Terhadap Keputusan Pembelian Produk Vape Di Instagram. Jurnal Emba: Jurnal Riset Ekonomi, Manajemen, Bisnis dan Akuntansi, Vol. 7(4), DOI: 10.35794/emba.v7i4.25701.

[13] Permana, A.I. (2020). Pengaruh Kualitas Website, Kualitas Pelayanan, dan Kepercayaan Pelanggan Terhadap Minat Beli Pelanggan Di Situs Belanja Online Bukalapak. Jurnal Ekonomi Bisnis, Vol. 25(2), pp. 94-109. DOI: 10.33592/jeb.v25i2.422.

[14] Girija, T., Asokumar, B. \& Meena, S. (2019). Influences of Website Quality and Service Quality on Consumer Satisfaction Among Online Food Ordering Consumer. International Journal of Recent Technology and Engineering (IJRTE), Vol. 8(3), pp. 3159-3163. DOI: $10.35940 /$ ijrte.C4894.098319.

[15] Chandra, W. \& Wirapraja, A. (2020). The Effect of Application Usability, Service Quality, and ESatisfaction on Purchase Intention of GoFood Customers. Indonesian Journal of Information Systems, Vol. 3(1), pp. 38-49. DOI: 10.24002/ijis.v3i1.3563. 